\section{Recertificación de médicos: iniciativa SEPAR}

Arcadi Gual

\section{Recertification of doctors: SEPAR initiative}

El desarrollo profesional continuo, los procesos para su acreditación y todas las iniciativas que la administración central y autonómica, las sociedades científicas y los colegios de médicos han ido tejiendo alrededor de este concepto han sido fundamentales para crear la conciencia colectiva de que la recertificación de los médicos es la vía coherente para garantizar la calidad de los actos profesionales y también para acercarnos a las normas internacionales. Además, la Unión Europea ha legislado en este sentido. Entre las diferentes iniciativas merece especial interés la Validación Periódica de la Colegiación (VPC), no por ser mejor o peor que otras, sino por ser la primera que ha logrado implementar el proceso de forma regular.

La recertificación de los médicos es una cuestión compleja en la que participan numerosos actores: políticos y representantes de la administración sanitaria, los colegios de médicos y, por supuesto, las sociedades científico-médicas. Pero siendo todos estos actores necesarios y con participación relevante, ninguno de ellos es fundamental. Cuando hablamos de recertificación hay dos protagonistas: el médico y el paciente o, si se prefiere, la profesión médica y la ciudadanía.

No es tan extraño oír 'esto de la recertificación no interesa a los médicos', 'los médicos ya tienen bastantes complicaciones con los recortes' o bien 'ahora que han perdido tanto valor adquisitivo, ¿hay que pedirles más sacrificios y exámenes?', pero para que les interese, es necesario explicarlo bien. Precisamente, en la mayor parte de los foros, cuando se explica que la recertificación representa una garantía de calidad para el paciente y una seguridad para el médico, el asentimiento es unánimemente favorable. No obstante, junto a esa unanimidad aparecen varias preguntas: ¿quién se encargará de la recertificación de los médicos?, ¿lo harán los colegios?, ¿lo harán las sociedades científicas?, ¿lo hará la administración?
Continuing professional development, the processes involved in its accreditation and all the initiatives that the central and autonomic authorities, scientific societies and medical associations have woven around this concept have played a vital role in creating a collective awareness of the fact that the recertification of doctors is the most coherent way to guarantee the quality of the professional actions, as well as bringing us closer to what is already the norm internationally. Moreover, the European Union has passed legislation in this sense. One of the initiatives that deserves special attention is Periodic Membership Validation, not because it is better or worse than any of the others, but because it is the first that has managed to implement the process on a regular basis.

The recertification of doctors is a complex issue that involves a number of different actors: politicians and representatives of the healthcare authorities, medical associations and, of course, scientificmedical societies. But although all these actors are necessary and play a relevant role, none of them are the fundamental elements. When we speak of recertification, there are two central characters: the doctor and the patient or, if you prefer, the medical profession and the general population.

It is not so unusual to hear things like 'doctors are not interested in this recertification thing,' 'doctors have already got enough on their plate with the cutbacks in spending' or 'now that they have lost so much purchasing power, do we have to ask them for more sacrifices and exams?' But before it can interest them, it has to be explained properly to them. In most forums, on explaining that recertification is a guarantee of quality for the patient and a safeguard for the physician, there is widespread agreement that it should be favoured. Yet, alongside this unanimity several questions also arise: Who will be responsible for the recertification of doctors? Will it be done by the medical associations? Will scientific societies do it? Will it be carried out by the authorities?
Director de la revista FEM-Fundación Educación Médica. E-mail: agual@ fundacioneducacionmedica.cat (c) 2015 FEM 
Todos ustedes, médicos o no, conocen la importancia de la relación médico-paciente. Esta relación es un contrato no escrito, un contrato tácito, pero real al fin y al cabo. Pues bien, la recertificación de los médicos termina con una credencial -válida por un tiempo determinado- que en sí misma es una pieza clave de otro contrato paralelo al del médicopaciente y que también es tácito: el contrato entre la profesión médica y la ciudadanía. Es responsabilidad primera y principal de los que conducen la profesión médica el mantener sanos ambos contratos, tanto el de médico-paciente como el de profesión médica-ciudadanía. Deben realizarlo por responsabilidad y han de ejercitarlo con transparencia. En entornos anglosajones, más transparentes que los nuestros, han potenciado mecanismos de recertificación y lo han hecho para preservar de una previsible crisis, de una posible rotura, el contrato profesión médica-sociedad.

¿Quién es responsable de que el contrato social, profesión médica-sociedad, navegue con buen rumbo? Como en todo contrato, hay dos partes: la profesión y la ciudadanía. Por parte de la profesión, la responsabilidad -no lo duden- recae en los profesionales y éstos están representados por los colegios de médicos y por las sociedades científicas médicas. Por la otra parte, la ciudadanía, la responsabilidad recae en sus representantes públicos, en sus parlamentarios. En una sociedad democrática, en la que ha quedado bastamente probado que la salud es un bien principal del estado del bienestar, son nuestros representantes quienes deberán garantizar el mejor de los estados de bienestar posibles, incluyendo la buena marcha (calidad y transparencia) del contrato profesión médica-sociedad.

Y la administración sanitaria, ¿qué papel desempeña en todo esto? Pues algo relevante y trascendente. La administración, como siempre ha sido, debe ser garante de que se haga lo que deba hacerse, de que se haga por quien sepa hacerlo y de que se haga bien. Y todo esto enmarcado en el principio de subsidiariedad que preside la Unión Europea y al que debemos acercarnos y esforzarnos cada día más. Así pues, para que las administraciones puedan garantizar sus responsabilidades en el contrato profesión médica-ciudadanía, no sólo no deben abstenerse o desentenderse de los procesos de recertificación de los médicos desarrollados por la otra parte del contrato -colegios de médicos y sociedades científicas-, sino que es necesario que conozcan y se involucren en los mecanismos y procesos de recertificación que los profesionales implementen. Sólo desde dentro podrá la administración garantizar al legislativo y a la sociedad que el con-
All of you, whether physicians or not, know how important the doctor-patient relationship is. Although this relationship is an unwritten contract, a tacit agreement, it is nonetheless real. The recertification of doctors also ends up with a credential, which is valid for a certain period of time and which in itself is a key component of another contract running parallel to that between doctor and patient. This other contract is also tacit and is the one that exists between the medical profession and the general population. The first and main duty of those that administer the medical profession is to ensure the health of both contracts - between physician and patient, and between the medical profession and the general population. It is their responsibility to do so and this must be carried out with transparency. In Englishspeaking settings, which are more transparent than ours, they have fostered recertification mechanisms, the reason being to avoid a foreseeable crisis, even a possible breakage, of the contract between the medical profession and society.

Who is responsible for ensuring that the social contract, between the medical profession and society, heads in the right direction? As in all contracts, there are two parties: the profession and the general population. For the profession, the responsibility undoubtedly falls upon the professionals themselves, who are represented by medical associations and by scientific-medical societies. For the general population, on the other hand, the responsibility is seen as belonging to their public representatives, their members of Parliament. In a democratic society, in which it has been proven that health is one of the main assets of the welfare state, our representatives are the ones who will have to ensure we have the best possible welfare states, which includes the smooth implementation (quality and transparency) of the contract between medical profession and society.

And what role do the healthcare authorities play in all this? Indeed, their role is relevant and of vital importance. The authorities, as has always been the case, must ensure that what has to be done is actually done, that it is done by those who know how to do it and that it is done well. All of this is included within the principle of subsidiarity promoted by the European Union to which we must strive to draw a little closer every day. Hence, for the authorities to be able to guarantee their responsibilities in the contract between the medical profession and the general population, they must avoid shying away from or pretending to ignore the processes of recertification of doctors carried out by the other party to the contract, i.e. medical associations and scientific societies. Instead, they need to be aware of and become involved 
trato entre los médicos y la ciudadanía camina por el sendero de la excelencia. Y si no fuera el caso de que el camino anduviera por la excelencia, deberá intervenir por responsabilidad.

En la primera semana de mayo se firmó un acuerdo entre el Consejo General de Colegios Oficiales de Médicos (CGCOM) y una sociedad científica, la Sociedad Española de Neumología y Cirugía Torácica SEPAR, que agrupa a neumólogos y a cirujanos torácicos, para complementar el programa de los colegios de médicos, la Validación Periódica de la Colegiación (VPC), con la recertificación de competencias de los médicos especialistas de SEPAR. Este acuerdo, denominado VPC-R.SEPAR, es el primer programa conjunto que se implementa de una manera práctica en España para otorgar una credencial de recertificación. Además, el proceso se inspira y respeta estrictamente el documento final aprobado por la Comisión de Formación Continuada del Sistema Nacional de Salud sobre el desarrollo profesional continuo y la evaluación del desarrollo profesional. La firma de este acuerdo con la SEPAR permitirá establecer sinergias entre colegios y sociedades científicas y, de alguna manera, abrirá el camino de la recertificación de los médicos. Desde el ámbito de la educación médica no podemos más que contemplar dicho acuerdo como el principio del buen hacer en los procesos de recertificación de los médicos españoles: a los responsables de esta aventura les deseamos perseverancia y suerte. in the mechanisms and processes of recertification implemented by the professionals. Only from within can the authorities offer the legislative powers and society itself a guarantee that the contract between physicians and the general population is treading the path of excellence. And if the path was eventually found not to be headed towards excellence, then it should intervene, because it has the responsibility to do so.

In the first week of May an agreement was signed between the Spanish General Council of Official Medical Associations (CGCOM) and a scientific society, the Spanish Pneumology and Thoracic Surgery Society (SEPAR, from the Spanish), which represents pneumologists and thoracic surgeons, to complement the programme of the medical associations, Periodic Membership Validation, with the recertification of the competences of the specialists belonging to the SEPAR. The agreement, which has been called VPC-R.SEPAR, is the first joint programme to be implemented in a practical manner in Spain for granting a recertification credential. Furthermore, the process is inspired by and complies strictly with the final document approved by the Continuing Education Commission of the Spanish National Health System about continuing professional development and the assessment of professional development. Signing this agreement with SEPAR will make it possible to establish synergies between associations and scientific societies and will somehow open up the way to the recertification of doctors. From the realm of medical education all we can do is to consider such an agreement as the first signs of starting to do things well in the processes involved in the recertification of Spanish doctors: we wish those responsible for this undertaking the best of luck and steadfastness in their dealings. 